\title{
Corporate Governance from an Islamic Moral Economy Perspective: The Dimensions and Analysis
}

\author{
Muhammad Rizky Prima Sakti ${ }^{*}$, Mohammad Ali Tareq², Hajime Kamiyama ${ }^{3}$ \\ ${ }^{1}$ University College of Bahrain, Kingdom of Bahrain \\ ${ }^{2}$ Malaysia-Japan International Institute of Technology, Universiti Teknologi Malaysia \\ ${ }^{3}$ Kushiro Public University of Economics, Japan \\ E-mail: ${ }^{1}$ mrizky@ucb.edu.bh, ${ }^{2}$ tareq@utm.my, ${ }^{3}$ kamiyama.hajime.gn@kushiro-pu.ac.jp
}

") Corresponding author

\section{JEL Classification:}

G34

$\mathrm{O} 16$

Received: March 15, 2021

Revised: June 15, 2021

Accepted: July 15, 2021

\begin{abstract}
Corporate governance from Islamic perspective is derived from Islamic worldview, whereby the God is at the apex and human beings are below Him. However, there is no unified definition of corporate governance under shariah point of view. To bridge the applicability of Islamic corporate governance model with Islamic moral economy framework, some key questions to be addressed are as follows. (i) do Islamic corporate governance models consistent with the aspiration of Islamic moral economy? (ii) what are the important dimensions of Islamic corporate governance? (iii) what is the concept of Islamic corporate governance inspired by the ideals of Islamic moral economy? To accomplish the objectives, this paper follows critical review analysis as a methodology, through which it aims to highlight how each Islamic corporate governance model models are being constructed and to compare those models with Islamic moral economy perspective. The paper proposes the suitable model of Islamic corporate governance under the Islamic moral economy perspective.
\end{abstract}

\section{Keywords:}

Corporate governance, Islam, Islamic Moral Econony, Dimensions.

How to Cite:

Sakti, M. R. P., Tareq, M. A., \& Kamiyama, H. (2021). Corporate Governance from an Islamic Moral Economy Perspective: The Dimensions and Analysis. Signifikan: Jurnal Ilmu Ekonomi, 10(2), 359-378. https://doi. org/10.15408/sjie.v10i2.21511. 


\section{Introduction}

The recent global financial crisis 2009 has gained interest in corporations and banking institutions worldwide. Many corporations and banking firms had to face big losses due to the result of poor governance practices. Amongst the lessons learned from the recent financial crisis is the importance of corporate governance framework to drive accountable, transparent, and efficient business operations. A proper and effective corporate governance structure is important to uplift the performance of any financial institutions. Prior studies in corporate governance literature have examined the relationship between corporate governance and performance (Chang et al., 2016; Crutchley \& Hansen, 1989; Daily et al., 2003). Nevertheless, the irregularities and inconclusive results pertaining the relationship are calling for the investigation of corporate governance from the Islamic perspective.

Bringing in the issue of Islamic finance, the unprecedented growth of Islamic banking and finance is likely to have important ramification to the Islamic economics and Muslim countries. Nonetheless, a critical analysis of the remarkable growth in Islamic banking and finance exhibit a contrary development. Islamic banking and finance do not seem to support the aspirations of Islamic moral economy, which emphasizes on both self-individual maximization (ihsan or excellence) and society well-being maximization ('adalah or social justice) (Asutay, 2013). An important consequence of these aspirations is expected to create corporate governance structure of Islamic corporations with the ultimate objective of creating of a just, participatory, and sharing socio-economic system. Deriving from the ethical propositions of Islam, Islamic corporate governance has a broad spectrum of all economic agents in corporations, encompassing the spiritual and material needs of Islamic community. Yet, studies on Islamic corporate governance have largely neglected the role of Islamic moral economy in essentializing corporate governance framework.

Based on the aforementioned above, this paper is aimed to: (i) discuss the models of Islamic corporate governance and its viability within Islamic Moral Economy perspective, (ii) identify the dimensions that are supposed to be vital for Islamic corporate governance, and (iii) re-defining the Islamic corporate governance by the axiomatic approach of Islamic Moral Economy. In achieving the above objectives, both conventional conceptions of corporate governance and the Islamic approach to corporate governance will be discussed. Moreover, the question whether the mainstream corporate governance structure is suitable for Islamic corporations will be addressed in shaping the analysis of this paper. Ghayad (2008), for instance, argues that the existence of shariah board in Islamic banks is substitute for the conventional board of directors. Similarly, Mohammed \& Muhammed (2017) regarded that the shari'ah board in Islamic banks is consistent with the stakeholder theory in mainstream governance literature. On the other hand, acknowledging that Islamic corporations operate based on shari'ah principles, Muneeza \& Hassan (2014) emphasize that mainstream corporate governance is different with the Islamic corporate governance; while the former is focus on retaining the rights of stakeholders; the latter is focus on preserving the Islamicity of corporations. 
To bridge the applicability of Islamic corporate governance models within the framework of Islamic moral economy, some key questions to be addressed are as follows. First, do Islamic corporate governance models consistent with the aspiration of Islamic moral economy? Second, what are the important dimensions of Islamic corporate governance? Third, what is the concept of Islamic corporate governance inspired by the ideals of Islamic moral economy? To accomplish the objectives, this paper follows critical review analysis as a methodology through which it aims to highlight each corporate governance models from both mainstream and Islamic perspective. Besides, the dimensions of corporate governance will be reviewed through manual read by author and calculated using NVivo 10 software.

This paper will fill the observed literature gap by make an assessment of Islamic corporate governance models and the mainstream corporate governance models, emphasizing the epistemology of Islamic moral economy. The paper, in turn, will propose the suitable model of Islamic corporate governance under the Islamic moral economy perspective. The paper suggests that corporate governance in Islam has a vast potential to create a just, participatory, and sharing society that is not only relegated to the removal of agency problems in Islamic corporations and retaining the rights of stakeholders. Nonetheless, this requires concerted efforts to creating participatory society as inspired by Islamic moral economy.

\section{Methods}

A qualitative descriptive approach was selected for this research because this approach is beneficial for studies to understand a selected phenomenon in corporate governance field. Kumar (2011) mentioned that a research that is emphasized on description rather than investigating relationships, is regarded as a descriptive research. A qualitative descriptive study aims to describe a particular situation, phenomenon, or describes attributes (dimensions) towards an issue. The data obtained by researcher is collected from first-hand observation through document analysis of corporate governance articles. A qualitative approach also allows the generation of comprehensive insights, for the purpose of this study, of corporate governance dimension from Islamic point of view.

In doing so, the keyword "corporate governance", "Islamic banks", and "Islamic perspective" were entered into the major research database such as Science Direct, Emerald Insight, Scopus Elsevier, Wiley-Blackwell, Springer, and Taylor \& Francis. This first process provides considerable articles in the form of journal articles, conference papers, reports, and thesis. A further step was undertaken to remove articles from database that use the keywords of corporate governance, Islamic banks, and Islamic perspective yet did not precisely address the issues of corporate governance per se. In sum, 57 articles were included in this study. The review employed articles published between 1990 and 2016. The starting point in 1990 was selected since the seminal paper such as Cadbury Report was released.

To form a deeper understanding of Islamic corporate governance, the characteristics/ 
dimensions of each article were reviewed through manual read by author and calculated the frequency of each characteristics using NVivo 10 software. If a corporate governance dimension considered by ten authors, hence, this dimension will then have a frequency of ten. These bulk lists of dimensions were listed in a descending order. Figure below exhibits the dimensions of corporate governance in Islamic banking and finance. In most cases, the dimensions of Islamic corporate governance are consistent with the report released by ISRA \& Thomson Reuters (2016). According to that report, there are nine corporate governance concepts related to Islamic banks, namely: (i) shari'ah scholars qualifications, (ii) synergies between scholars and practitioners, (iii) standardization, (iv) Accountability, (v) responsibility, (vi) transparency, (vii) trustworthiness, (viii) independence, and (ix) competency.

\section{Result and Discussion}

\section{Corporate Governance from Islamic Perspective}

Islamic Financial Services Board (IFSB) defines corporate governance as a set of relationship between a company management, board of directors, shareholders, and other stakeholders that provide the structure through which the objectives of the companies are set and the means of obtaining the objectives are determined according to Islamic principles. Corporate governance is not a new phenomenon in Islam. The fundamental of organizing the contractual relationship between partners with respect to the division of responsibilities has been continuously practiced in earlier civilizations (Alnasser et al., 2012). Islam stipulates the concept of writing all forms of transactions and the contract should be free from any exploitation. From maqasid al-shariah ${ }^{1}$ (objectives of shari'ah) perspective, corporate governance is the process and structure in managing business and affairs of the company with the goal of maximization of shareholders wealth within the values and principles of maqasid al-shariah (Dusuki, 2012). This maqasid is the backbone of Islamic banking business and operations. To uphold shari'ah compliance principles and ascertain the stakeholders of what Islamic bank doing so, hence corporate governance is necessitated (Ginena, 2014).

If we trace back from the primary sources of Islam, the concept of corporate governance has mentioned several times in the Holy Qur'an, which indicate the essential elements of corporate governance practices. For example, Allah SWT enjoins Muslim to satisfy all of their contracts (Al-Ma'idah, 5:1).

"O ye who believe! Fulfil (all) obligations" (Al-Ma'idah, 5:1).

In another verse, Allah SWT prohibits of betraying any trust (Al-Anfal, 8:27)

"O ye who believe! Betray not the trust of Allah and the apostle, nor misappropriate knowingly things entrusted to you (Al-Anfal, 8:27)

\footnotetext{
Maqasid al-shariah is the ultimate objectives of Islamic law which consisting of protection of religion (ad-din), protection of life $(a n-n a f s)$, protection of posterity (an-nasl), protection of intellect (al-aql), and protection of wealth (al-mal). This maqasid has an importance in determining the level of maslahah (benefit) and mafasid (evil) that existed in particular case, including in the case of Islamic banks
} 
Allah SWT prohibits the Believers of deriving income from cheating, price manipulation, dishonesty or fraud (An-Nisa, 4: 29)

"O ye who believe! Eat not up your property among yourselves in vanities. But let there be amongst you traffic and trade by mutual goodwill, nor kill (or destroy) yourselves, for verily Allah hath been to you Most Merciful!" (An-Nisa, 4:29)

Another verse of Holy Qur'an mentioned about minimizing problems due to asymmetric information between contracting parties.

"Disdain not to reduce to writing (your contract) for a future period, whether it be small or big; it is just in the sight of Allah, more suitable as evidence, and more convenient to prevent doubts among yourselves." (Al-Baqarah, 2: 282)

To date, there is a rising concern of Islamic scholars on the issues of corporate governance (Abu-Tapanjeh, 2009; Bhatti \& Bhatti, 2009; Choudhury \& Hoque, 2006; Iqbal \& Mirakhor, 2004; Safieddine, 2009). Nevertheless, from the prior literature, we find that there is no precise definition of corporate governance from Islamic perspective. Indeed, the researchers have no agreement whether Islamic principles of corporate governance do differ from conventional principles or not. On one hand, one group of scholars mention that the corporate governance in conventional framework is no much differ within the Islamic paradigm (Bhatti \& Bhatti, 2009). By definition, corporate governance is "the system by which companies are managed and controlled to achieve the corporate objectives and preserving the stakeholders' rights and interests. The peculiarity of corporate governance within the Islamic point of view lies on specific characteristics and features as compared to conventional paradigm. On the other hand, others group of scholars believe that governance framework in Islam do differ from the conventional counterpart (Abu-Tapanjeh, 2009; Choudhury \& Hoque, 2006). Governance structure in Islam must follow the shariah principles and should realize the objectives of social well-being.

Choudhury \& Hoque (2006) raised several concerns about the comparison of corporate governance framework from conventional and Islamic perspective. The paper considers that the faith-based theoretical framework of corporate governance and the theory of decision-making process based on the Islamic epistemology of Tawhid ${ }^{2}$. The importance implications of the idea of corporate governance based on the premises of Tawhid are enormous, inter alia, all stakeholders are driven by the objective of Tawhid or Oneness of God. This practical implication is much differing from conventional framework of corporate governance whereby the management of organizations undertaken by the board of directors, management, employees, and shareholders are driven by wealth maximization objectives. In addition to that, corporate governance from mainstream perspective based on the rationalism epistemology that seeks to provide rational explanations of social affairs (Shibani \& Fuentas, 2017). Researchers who abide this view believe that corporate governance is a technical matter and emphasize on the aspect of corporate finance. Corporate governance from this mainstream perspective seeks to solve agency problem

${ }^{2}$ Tawhid is oneness of God, unity of knowledge, Allah SWT. It is the fundamental concept and hold that God (Allah SWT) is One (Al-Ahad) and Single (Al-Wahid). This fundamental epistemology relates to all issues of life. 
arising from separation of ownership and control in the company (Ardalan, 2007). Regardless of the models of corporate governance (Anglo-Saxon and European models), they share the same objective of reducing agency problems.

Another research by Abu-Tapanjeh (2009) points that corporate governance in Islamic perspective has vast horizon and relatively larger compared to OECD principles. The striking difference between the two is that corporate governance in OECD entitles the decision-making process and business participation dealings to limited number of people, for instance BOD and senior management. In Islamic corporate governance, however, all stakeholders have equal rights and responsibilities to involve in corporate governance process. In addition, all actions and responsibilities fall under the jurisdiction of Islam, while the OECD principles are based on six different issues and obligations. Abu-Tapanjeh (2009) argues that the Islamic principles of corporate governance is in harmony with many principles proposed by the OECD. Table 1 delineates the common principles of corporate governance from both conventional and Islamic perspective.

Table 1. The Comparison of Corporate Governance Practices Between OECD and Islamic Perspective

\begin{tabular}{cll}
\hline No & \multicolumn{1}{c}{ OECD Principles } & \multicolumn{1}{c}{ Islamic Principles } \\
\hline 1 & $\begin{array}{l}\text { Promote transparent and efficient markets, } \\
\text { coupled with the rule of law }\end{array}$ & $\begin{array}{l}\text { Promotion of business within ethical } \\
\text { framework of shari'ah }\end{array}$ \\
2 & $\begin{array}{l}\text { Protect and facilitate the exercise of } \\
\text { shareholders right }\end{array}$ & Property as trust from God \\
3 & $\begin{array}{l}\text { Ensure the equitable treatment of all } \\
\text { shareholders, including minority and foreign } \\
\text { shareholders }\end{array}$ & $\begin{array}{l}\text { Equitable distributions of wealth to all } \\
\text { stakeholders and disadvantages members in } \\
\text { the form of zakat and sadagah }\end{array}$ \\
4 & $\begin{array}{l}\text { Recognize the rights of stakeholders established } \\
\text { by law }\end{array}$ & $\begin{array}{l}\text { Islamic accountability to falah and social } \\
\text { welfare orientation }\end{array}$ \\
5 & $\begin{array}{l}\text { Ensure that timely and accurate disclosure } \\
\text { is made on all material matters regarding the } \\
\text { corporation }\end{array}$ & $\begin{array}{l}\text { Accountability with shari'ah compliance, wider } \\
\text { accountability with written as well as oral } \\
\text { disclosure }\end{array}$ \\
\hline
\end{tabular}

Source: adopted from Abu-Tapanjeh (2009)

In addition to work of Abu-Tapanjeh (2009), Bhatti \& Bhatti (2009) provide Islamic corporate governance model based on Hisbah institution. The peculiarity of Islamic corporate governance lies in two main aspects: (i) It is driven by shari'ah law and governs all aspects of an individual life; (ii) It is needed to consider the effect of shariah law and Islamic financial transactions on corporate governance practices. Unlike conventional framework, the ultimate objective of Islamic corporate governance is to realize maqasid al-shariah. It is beyond the focus of conventional approach that is more 'shareholdercentric', whereas Islamic corporate governance is more to the 'stakeholder theory' that promotes transparency and accountability. The paper had traced the Islamic corporate governance model from classical history of Islam. They believe that Hisbah institution represented a core element of Islamic corporate governance in early Muslim society. This 
institution performs the duties of market inspection and ensuring all market activities are in accordance with shariah principles. Nonetheless, they cast a doubt whether such a system can be revived in its traditional form and how this can be applied in Muslim countries where corruption is already widespread.

Bringing on the issue of Stakeholder Theory from Islamic perspective, some scholars believed that Stakeholder Theory is important to understand how corporate governance works. For example, Iqbal \& Mirakhor (2004) raised several concerns about stakeholder's model and governance in Islamic economic system. They posit that stakeholder model of corporate governance finds strong foundation in the Islamic economics. They discovered that Islamic concept of property rights and Islamic law of contract from both explicit and implicit contracts are the basis for stakeholder theory of corporate governance. This causes them to further propose that all stakeholders ought to be included into decision making activities of the firm's, whereas the objective of the firm is to preserve the interests of all stakeholders not only those of just shareholders. A critical review of this paper reveals that the concepts of stakeholder theory and corporate governance are well articulated with convincing arguments and used by two prominent scholars by emphasize on the rules of behavior or Islamic norms. Hence, according to them, these lead to recognize the role of stakeholders in decision making of a firm. However, far too little attention has been paid to show how to ensure that property rights are protected in Islamic economic system.

Critically examines, Chapra (2004) commented the work of Iqbal \& Mirakhor (2004) on stakeholder model of governance in Islamic economic system. According to him, the paper has valuable contributions to ascertain and justify the stakeholder theory that has been rooted from Islamic principles. Nonetheless, he pointed out that the Islamic norms of behavior do not automatically protecting the stakeholders' rights. The existence of moral values or Islamic norms of behavior on stakeholder's rights will not be adequate. Consequently, according to Chapra, it is necessary to have an effective socio-economic mechanism based on incentives and deterrents to protect the stakeholders' rights.

Another research by Dusuki (2012) has proposed that the pyramid of maslahah as a viable tool to devise a decision-making process and managing conflicts arising from different stakeholders in IFIs. His finding is consistent with findings of past studies by Iqbal \& Mirakhor (2004), which showed that stakeholder theory in Islamic perspectives provide a strong basis of corporate governance framework. The uniqueness of this study exists in the fact that the application of the pyramid of maslahah on stakeholder management in IFIs. For example, managers of the firms ought to protect the basic needs of their employees by a way of providing sufficient and convenient prayer rooms and guarantying the safety of their employees. This example reflects the protection of religion and life that is constituted as essential or fundamental responsibilities (daruriyyat) to be fulfilled by IFIs.

From the aforementioned above, we can conclude that there are three main models of corporate governance from Islamic perspective: (i) Tawhid based model, (ii) Maqasid Al-Shariah based model, and (iii) Stakeholder based model of corporate governance. 
Tawhid (Oneness of God) based model refers to corporate governance mechanism that derived from the principle of consultation (shura) whereby all stakeholders are driven by the same objective of Tawhid or Oneness of God (Choudhury \& Hoque, 2006; Abu-Tapanjeh, 2009). The maqasid al-shariah based model concerns on the practices of corporate governance with the ultimate goal to realize maqasid al-shariah (Bhatti \& Bhatti, 2009; Lahsasna, 2014). Next, the stakeholder based model of corporate governance dealings with applying the stakeholders' value system with some modifications according to the Islamic norms behaviour in order to protecting the stakeholders' rights (Iqbal \& Mirakhor, 2004; Chapra, 2004; Dusuki, 2012).

Figure 1. Dimensions of Corporate Governance in Islamic Banking and Finance

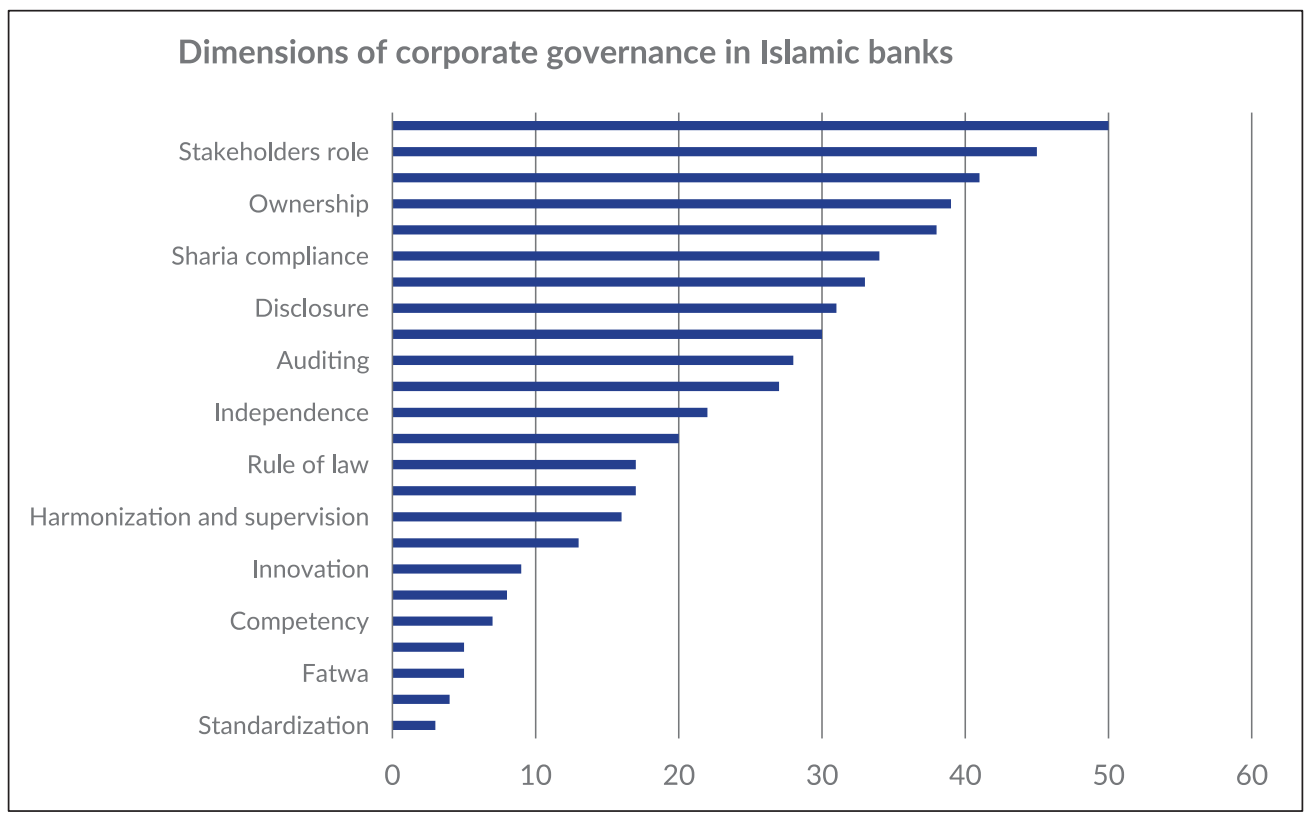

\section{Dimensions of Islamic Corporate Governance}

As we argued earlier, studies in corporate governance literature oftentimes have different interpretations and dimensions from Islamic point of view. As a matter of fact, there is little agreement in the use of corporate governance principles or dimensions from Islamic perspective. Accordingly, although the literature is reasonably broad however lacks of consistency and strong underpinning principles. Therefore, in this section we present the synthesis of literature on corporate governance from Islamic perspective and identifying the broad dimensions that have been employed in the study of corporate governance from Islamic banking and finance.

It was not surprising to find that different researchers have different characteristics of corporate governance because of their differences in the definition of governance. For example, Choudhury \& Haque (2006) have identified the characteristics of governance in Islamic corporations are shuratic process, shari'ah rules, effectiveness, accountability social responsibility. Meanwhile, Abu-Tapanjeh (2009) states that Islamic principles of corporate governance are identified from shareholders right, equitable, stakeholders' role, disclosure, 
transparency, and responsibility. Conversely, Zain et al. (2015) included accountability, sharia compliance, performance, and consultation as important dimensions for shariah governance. (See details in Figure 1)

Table 2. Identified Dimensions of Corporate Governance in Islamic Banking and Finance

\begin{tabular}{cl}
\hline Dimension & \multicolumn{1}{c}{ Citation References } \\
\hline Sharia scholars & Abdel-Baki \& Leone Sciabolazza, 2014; Abdullah, Percy, \& Stewart, 2015; Abu, Jasin, Abdul \\
& Razak, \& Sharif, 2014; Abu-Tapanjeh, 2009; Ahmad \& Omar, 2016; Ahmed, 2014; Akhtar, 2006; \\
& Al-Beshtawi et al., 2014; Al-Malkawi et al., 2014; Alnasser \& Muhammed, 2012; Al-Sadah, \\
& 2007; Archer et al., 1998; Bakar, 2011; Bhatti \& Bhatt, 2009; Bukair \& Abdul Rahman, 2015; \\
& Bukhari et al., 2013; M. Umer Chapra \& Ahmed, 2002; Choudhury \& Hoque, 2006; Dalwai et al., \\
& 2015; Darmadi, 2013; Ghayad, 2008; Ginena, 2014; Grassa, 2013, 2016; Hamza, 2013; Haniffa \\
& \& Hudaib, 2013; Hasan, 2009, 2012; Hashim, Mahadi, \& Amran, 2015; N. A. Ismail \& Razak, \\
& 2014; ISRA \& Thomson Reuters, 2016; Lewis, 2005; Mizushima, 2013; Mollah \& Zaman, 2015; \\
& Muneeza, 2014; Nathan \& Ribière, 2007; Rosly, 2010; Safieddine, 2009; Shafii, Ali, \& Kasim, \\
& 2014; Shahzad Bukhari, Awan, \& Ahmed, 2013; Elias, 2015; Srairi, 2015; Ullah, 2014; Wijethunga \\
& \& Ekanayake, 2015; Wilson, 2009; Zain, Zulkarnain, \& Hassan (2015) \\
\hline
\end{tabular}

Stakeholders role Abdel-Baki \& Leone Sciabolazza, 2014; Abdullah et al., 2015; Abu et al., 2014; Abu-Tapanjeh, 2009; Ahmad \& Omar, 2016; Ahmed, 2014; Akhtar, 2006; Al-Beshtawi et al., 2014; Al-Malkawi et al., 2014; Alnasser \& Muhammed, 2012; Al-Sadah, 2007; Archer et al., 1998; Bakar, 2011; Bhatti \& Bhatti, 2009; Bukair \& Abdul Rahman, 2015; Bukhari et al., 2013; M. Umer Chapra \& Ahmed, 2002; Muhammad Umer Chapra, 2004; Dalwai et al., 2015; Darmadi, 2013; Dusuki, 2012; Ghayad, 2008; Ginena, 2014; Grassa, 2013, 2016; Hamza, 2013; Haniffa \& Hudaib, 2013; Hasan, 2009, 2012; Hashim et al., 2015; labal \& Mirakhor, 2004; N. A. Ismail \& Razak, 2014; ISRA \& Thomson Reuters, 2016; Kasim, Ibrahim, \& Sulaiman, 2009; Mizushima, 2013; Nathan \& Ribière, 2007; Shafii et al., 2014; Shahzad Bukhari et al., 2013; Elias, 2015; Srairi, 2015; Ullah, 2014; Zain et al (2015)

Responsibility Abdel-Baki \& Leone Sciabolazza, 2014; Abdullah et al., 2015; Abu et al., 2014; Abu-Tapanjeh, 2009; Ahmed, 2014; Akhtar, 2006; Al-Beshtawi et al., 2014; Al-Malkawi et al., 2014; Alnasser \& Muhammed, 2012; Al-Sadah, 2007; Archer et al., 1998; Bakar, 2011; Bhatti \& Bhatti, 2009; Bouzenita, 2012; Bukair \& Abdul Rahman, 2015; M. Umer Chapra \& Ahmed, 2002; Choudhury \& Hoque, 2006; Darmadi, 2013; Dusuki, 2012; Ghayad, 2008; Ginena, 2014; Grassa, 2013; Hamza, 2013; Haniffa \& Hudaib, 2013; Hasan, 2009, 2012; ISRA \& Thomson Reuters, 2016; Kasim et al., 2009; Lewis, 2005; Mizushima, 2013; Muneeza, 2014; Nathan \& Ribière, 2007; Rosly, 2010; Safieddine, 2009; Shafii et al., 2014; Srairi, 2015; Wijethunga \& Ekanayake, 2015; Wilson, 2009; Zain et al., (2015)

Ownership Abdallah, Hassan, \& McClelland, 2015; Abdel-Baki \& Leone Sciabolazza, 2014; Abdullah et al., 2015; Abu-Tapanjeh, 2009; Ahmad \& Omar, 2016; Ahmed, 2014; Akhtar, 2006; Al-Beshtawi et al., 2014; Al-Malkawi et al., 2014; Alnasser \& Muhammed, 2012; Al-Sadah, 2007; Archer et al., 1998; Bakar, 2011; Ben Slama Zouari \& Boulila Taktak, 2014; Bukair \& Abdul Rahman, 2015; Bukhari et al., 2013; M. Umer Chapra \& Ahmed, 2002; Dalwai et al., 2015; Dusuki, 2012; Ghayad, 2008; Grassa, 2013, 2016; Hamza, 2013; Hasan, 2012; Hashim et al., 2015; Kasim et al., 2009; Lewis, 2005; Mizushima, 2013; Mollah \& Zaman, 2015; Nathan \& Ribière, 2007; Shahzad Bukhari et al., 2013; Elias, 2015; Srairi, 2015; Ullah, 2014; Wijethunga \& Ekanayake, 2015; Zain et al (2015)

Transparency

Abdallah et al., 2015; Abdel-Baki \& Leone Sciabolazza, 2014; Abdullah et al., 2015; Abu et al., 2014; Abu-Tapanjeh, 2009; Ahmad \& Omar, 2016; Akhtar, 2006; Al-Beshtawi et al., 2014; AlMalkawi et al., 2014; Al-Sadah, 2007; Archer et al., 1998; Archer \& Rifaat, 2013; Bakar, 2011; Ben Slama Zouari \& Boulila Taktak, 2014; Bhatti \& Bhatti, 2009; Bukair \& Abdul Rahman, 2015; M. Umer Chapra \& Ahmed, 2002; Muhammad Umer Chapra, 2004; Choudhury \& Hoque, 2006; Dalwai et al., 2015; Darmadi, 2013; Dusuki, 2012; Ghayad, 2008; Hashim et al., 2015; N. A. Ismail \& Razak, 2014; Mizushima, 2013; Nathan \& Ribière, 2007; Safieddine, 2009; Shahzad Bukhari et al., 2013; Elias, 2015; Srairi (2015)

Sharia compliance

Abdel-Baki \& Leone Sciabolazza (2014); Abdullah et al., 2015; Abu et al., 2014; Abu-Tapanjeh, 2009; Ahmed, 2014; Akhtar, 2006; Al-Beshtawi et al., 2014; Al-Malkawi et al., 2014; Alnasser \& Muhammed, 2012; Al-Sadah, 2007; Bakar, 2011; Bukhari et al., 2013; M. Umer Chapra \& Ahmed, 2002; Dalwai et al., 2015; Darmadi, 2013; Ginena, 2014; Grassa, 2013; Hamza, 2013; Hashim et al., 2015; N. A. Ismail \& Razak, 2014; ISRA \& Thomson Reuters, 2016; Kasim et al., 2009; Lewis, 2005; Mizushima, 2013; Nathan \& Ribière, 2007; Safieddine, 2009; Shafii et al., 2014; Shahzad Bukhari et al., 2013; Elias, 2015; Srairi, 2015; Ullah, 2014; Wijethunga \& Ekanayake, 2015; Wilson, 2009; Zain et al (2015) 
Signifikan: Jurnal IImu Ekonomi

Volume 10 (2), 2021: 359 - 378

\begin{tabular}{ll}
\hline Dimension & \multicolumn{1}{c}{ Citation References } \\
\hline Performance & Abdallah et al., 2015; Abdel-Baki \& Leone Sciabolazza, 2014; Abdullah et al., 2015; Abu-Tapanjeh, \\
& 2009; Ahmad \& Omar, 2016; Al-Malkawi et al., 2014; Alnasser \& Muhammed, 2012; Al-Sadah, \\
& 2007; Archer et al., 1998; Bakar, 2011; Ben Slama Zouari \& Boulila Taktak, 2014; Bukair \& Abdul \\
& Rahman, 2015; Bukair \& Rahman, 2015; Bukhari et al., 2013; M. Umer Chapra \& Ahmed, 2002; \\
& Choudhury \& Hoque, 2006; Dalwai et al., 2015; Darmadi, 2013; Dusuki, 2012; Ghayad, 2008; \\
& Grassa \& Matoussi, 2013; Grassa, 2016; Hasan, 2012; Iqbal \& Mirakhor, 2004; ISRA \& Thomson \\
& Reuters, 2016; Lewis, 2005; Mollah \& Zaman, 2015; Rosly, 2010; Safieddine, 2009; Srairi, 2015; \\
& Ullah, (2014) \\
\hline Disclosure & Abdallah et al (2015); Abdel-Baki \& Leone Sciabolazza (2014); Abdullah et al (2015); Abu et al \\
& (2014); Abu-Tapanjeh (2009); Ahmad \& Omar (2016); Akhtar (2006); Al-Beshtawi et al (2014); Al- \\
& Malkawi et al (2014); Alnasser \& Muhammed (2012); Al-Sadah (2007); Archer et al (1998); Archer \\
& \& Rifaat (2013); Bakar (2011); Bhatti \& Bhatti (2009); Bukair \& Abdul Rahman (2015); Bukhari \\
& et al (2013); M. Umer Chapra \& Ahmed (2002); Dalwai et al (2015); Ginena (2014); Haniffa \& \\
& Hudaib (2013); Hashim et al (2015); ISRA \& Thomson Reuters (2016); Mizushima (2013); Mollah \\
& \& Zaman (2015); Safieddine (2009); Shahzad Bukhari et al (2013); Srairi (2015) \\
\hline
\end{tabular}

Shareholder right Abu-Tapanjeh (2009); Ahmad \& Omar (2016); Ahmed (2014); Akhtar (2006); Al-Malkawi et al (2014); Alnasser \& Muhammed (2012); Al-Sadah (2007); Archer et al (1998); Archer \& Rifaat (2013); Bakar (2011); Ben Slama Zouari \& Boulila Taktak (2014); Bhatti \& Bhatti, (2009); Bukhari et al (2013); Muhammad Umer Chapra (2004); Darmadi (2013); Dusuki (2012); Ghayad (2008); Grassa (2013, 2016); Hasan (2009, 2012); Hashim et al (2015); Iqbal \& Mirakhor (2004); ISRA \& Thomson Reuters (2016); Lewis (2005); Mollah \& Zaman (2015); Nathan \& Ribière (2007); Rosly, (2010); Wijethunga \& Ekanayake (2015)

Auditing Abdullah et al (2015); Abu-Tapanjeh (2009); Ahmad \& Omar (2016); Al-Beshtawi et al (2014); Al-Malkawi et al (2014); Al-Sadah (2007); Archer et al (1998); Archer \& Rifaat (2013); Bakar (2011); Bukair \& Abdul Rahman (2015); M. Umer Chapra \& Ahmed (2002); Ginena (2014); Haniffa \& Hudaib (2013); N. A. Ismail \& Razak (2014); ISRA \& Thomson Reuters (2016); Kasim et al (2009); Lewis (2005); Mizushima (2013); Muneeza (2014); Nathan \& Ribière (2007); Rosly (2010); Safieddine (2009); Shafii et al (2014); Srairi (2015); Ullah (2014); Wijethunga \& Ekanayake (2015)

Risk management Abdallah, Hassan, \& McClelland (2015); Abdel-Baki \& Leone Sciabolazza (2014); Abdullah, Percy, \& Stewart (2015); Ahmed (2014); Akhtar (2006); Al-Malkawi, Pillai, \& Bhatti (2014); AlSadah (2007); Archer, Karim, \& Al-Deehani (1998); Archer \& Rifaat (2013); Bukair \& Rahman (2015); Chapra \& Habib (2002); Dalwai, Basiruddin, \& Abdul Rasid (2015); Darmadi (2013); Ginena (2014); Grassa (2013); Hamza (2013); Ismail \& Razak (2014); ISRA \& Thomson Reuters (2016); Mizushima (2013); Rosly (2010); Safieddine (2009); Srairi (2015); Wijethunga \& Ekanayake, (2015)

Independence $\quad$ Al-Beshtawi, Zraqat, \& Al -Hiyasat (2014); Alnasser \& Muhammed (2012); Al-Sadah (2007); Bakar (2011); Chapra \& Habib (2002); Dalwai et al. (2015); Darmadi (2013); Grassa (2013); Hamza (2013); Hashim, Mahadi, \& Amran (2015); ISRA \& Thomson Reuters (2016); Kasim, Ibrahim, \& Sulaiman (2009); Mizushima (2013); Mollah \& Zaman (2015); Nathan \& Ribière (2007); Safieddine (2009); Srairi (2015); Wilson (2009)

Accountability Abu-Tapanjeh (2009); Ahmad \& Omar (2016); Alnasser \& Muhammed (2012); Al-Sadah (2007); Bakar (2011); Bhatti \& Bhatti (2009); Bukair \& Abdul Rahman (2015); Chapra \& Habib (2002); Darmadi (2013); Dusuki (2012); Haniffa \& Hudaib (2013); Hasan (2009); Iqbal \& Mirakhor (2004); ISRA \& Thomson Reuters (2016); Kasim, Ibrahim, \& Sulaiman (2009); Lewis (2005); Mizushima (2013); Mollah \& Zaman, (2015)

Effectiveness Alam Choudhury \& Ziaul Hoque (2006); Al-Beshtawi, Zraqat, \& Al -Hiyasat (2014); Al-Malkawi, Pillai, \& Bhatti (2014); Alnasser \& Muhammed (2012); Al-Sadah (2007); Bukair \& Abdul Rahman (2015); Bukhari, Awan, \& Ahmed (2013); Chapra \& Habib (2002); Hamza (2013); Mizushima (2013); Mollah \& Zaman (2015); Noor Azian Ismail \& Shaikh Hamzah Abdul Razak (2014); Safieddine (2009); Shahzad Bukhari, Awan, \& Ahmed (2013); Wilson (2009)

Rule of law Abdullah, Percy, \& Stewart (2015); Abu-Tapanjeh (2009); Ahmad \& Omar (2016); Ahmed (2014); Alnasser \& Muhammed (2012); Bakar (2011); Bhatti \& Bhatti (2009); Darmadi (2013); Ghayad (2008); Grassa (2013); ISRA \& Thomson Reuters (2016); Lewis (2005); Muneeza (2014); Rosly (2010); Wijethunga \& Ekanayake (2015); Wilson (2009)

Harmonization Abdullah et al (2015); Akhtar (2006); Alnasser \& Muhammed (2012); Al-Sadah (2007); Archer, Karim, \& Al-Deehani (1998); Bukair \& Abdul Rahman (2015); Chapra \& Habib (2002); Ghayad (2008); Ginena (2014); Grassa (2013); Hamza (2013); ISRA \& Thomson Reuters (2016); Lewis (2005); Mollah \& Zaman (2015); Safieddine (2009); Ullah (2014) 


\begin{tabular}{ll}
\hline \multicolumn{1}{c}{ Dimension } & \multicolumn{1}{c}{ Citation References } \\
\hline Culture & $\begin{array}{l}\text { Abdallah, Hassan, \& McClelland (2015); Ahmed (2014); Bakar (2011); Bukair \& Abdul Rahman } \\
\text { (2015); Bukhari, Awan, \& Ahmed (2013); Chapra \& Habib (2002); Darmadi (2013); Grassa \& } \\
\text { Matoussi (2013); Haniffa \& Hudaib (2013); Hashim, Mahadi, \& Amran (2015); Mizushima (2013); } \\
\text { Nathan \& Ribière (2007); Shahzad Bukhari, Awan, \& Ahmed (2013) }\end{array}$ \\
\hline Innovation & $\begin{array}{l}\text { Abu, Jasin, Abdul Razak, \& Sharif (2014); Abu-Tapanjeh (2009); Ahmed (2014); Akhtar (2006); } \\
\text { Ghayad (2008); Hasan (2012); ISRA \& Thomson Reuters (2016); Nathan \& Ribière (2007); Rosly } \\
\text { (2010) }\end{array}$ \\
\hline Strategic vision & $\begin{array}{l}\text { Abu-Tapanjeh (2009); Bakar (2011); Grassa (2013); Hasan (2009); Hashim, Mahadi, \& Amran } \\
\text { (2015); Mizushima (2013); Nathan \& Ribière (2007) }\end{array}$ \\
\hline Competency & $\begin{array}{l}\text { Alnasser \& Muhammed (2012); Bakar (2011); ISRA \& Thomson Reuters (2016); Mizushima } \\
\text { (2013); Mollah \& Zaman (2015); Shafii, Ali, \& Kasim (2014); Wilson, (2009) }\end{array}$ \\
\hline Fatwa & $\begin{array}{l}\text { Alnasser \& Muhammed (2012); Ginena (2014); Grassa (2013); Hamza, (2013); ISRA \& Thomson } \\
\text { Reuters (2016) }\end{array}$ \\
\hline Trust (Amanah) & $\begin{array}{l}\text { Abu-Tapanjeh (2009); Archer \& Rifaat (2013); Hasan, (2012); Iqbal \& Mirakhor (2004); Nathan \& } \\
\text { Ribière (2007) }\end{array}$ \\
\hline Efficiency & Ahmed (2014); Al-Beshtawi, Zraqat, \& Al -Hiyasat (2014); Bakar (2011); Chapra \& Habib (2002) \\
\hline Standardization & Akhtar (2006); Hamza (2013); ISRA \& Thomson Reuters (2016) \\
\hline
\end{tabular}

In sum, there are 24 identified dimensions of corporate governance from the analysis. Most of these dimensions also recognized in corporate governance from conventional literature. Moreover, the most frequently dimensions of governance from Islamic perspective can be named as follows: (1) sharia scholars, (2) stakeholders role, (3) responsibility, (4) ownership, (5) transparency, and (6) sharia compliance. Each of these frequent dimensions was mentioned in more than 30 articles respectively. In addition, two-third of all dimensions investigated in the corporate governance literature pertinent to the context of Islamic banking and finance being examined by author. Table 2 shows the citation references for each identified dimensions of corporate governance in Islamic banking and finance.

\section{Islamic Moral Economy and Its Association With Corporate Governance}

Islamic moral economy has emerged in the post 1960s as a result of the failure of economic development and the rise in Islamic political identity in Muslim countries. The concept of Islamic moral economy is proposed as a response of the failure of mainstream economic systems, whether capitalist or socialist, with derived from the primary sources of Islam, namely the Qur'an and the Sunnah (Asutay, 2013). The advocates of Islamic moral economy argue that this economic system is designed to develop Islamic system of economics and economy in realizing maqasid al-shariah (the objectives of shariah) and achieving sustainable development and social justice (Chapra, 2000). The concepts and principles such as 'adalah' or justice and 'haqq' or right are the core of Islamic moral economy.

As embodied in Islamic economic system, there are four elements of Islamic values that should be existed in Islamic banking and finance. First, since Islamic banking and finance industry is derived from the ontology of Islam, this industry prohibits all 
activities and transactions involving riba (interest-based transactions), gharar (speculation), maisir (gambling), and any products that violates Islamic norms such as liquor, tobacco, pornography, weapons, etc. Second, this industry promotes the risk-sharing model based on profit-loss sharing (PLS) contracts such as mudarabah and musharakah. Third, the financing activities in Islamic finance promote the real economy and maintaining stability. Fourth, the financing activities also determined by non-economic factors, such as religions (Islam), reciprocity, altruism, and distribution.

All of those elements are the articulation and operationalization of maqasid alshariah or the objectives of shariah. Hence, the objective of Islamic moral economy is not only focusing on economic growth, but also rather promoting human well-being and socio-economic development. Beyond this objective, Islamic moral economy is aimed to realize 'ihsan' or beneficence/excellence and 'falab' or salvation in the world and hereafter. Hence, Islamic moral economy is a moral system of economy and society through multidimensional and multidisciplinary approach by essentializing social justice, equality, sharing economy, and participatory in the society.

Bringing in the issue of Islamic corporate governance, as we argued earlier, there is no precise definition of corporate governance from Islamic perspective. Nonetheless, that there are three main models of corporate governance from Islamic perspective: (i) Tawhid based model, (ii) Maqasid Al-Shariah based model, and (iii) Stakeholder based model of corporate governance. Looking critically, none of those models essentializing the value principles of Islamic moral economy. Islamic corporate governance is reduced to the mere protection of stakeholders rights and removal of agency problems within Islamic corporations. Rather than establishing a just, participatory, and sharing socioeconomic system, Islamic corporate governance has been pursuing the same objectives as conventional corporate governance. This trend on Islamic corporate governance has deviate away from the aspiration of Islamic moral economy to reconcile self-individual interest with society welfare interest. It is therefore imperative to make reference to the values and principles of Islamic corporate governance as formulated by the Islamic moral economy. For this reason, the framework of Islamic moral economy should be articulated and Islamic corporate governance should be positioned within this framework.

Aside from that, we observe that corporate governance models from Islamic perspective is derived from Islamic worldview, whereby the God is at the apex and human beings are below Him (Muneeza, 2013). Regardless of the corporate governance models embraced by the IFIs, the basic structure shall be abiding to the God and then to the BOD and stakeholders. Unlike the structure of corporate governance from mainstream perspective in which the company discharging its duties to the BOD and then stakeholders. Accordingly, we proposed the corporate governance model from Islamic view based on that basis. Figure 2 below shows the Islamic corporate governance model, which the author proposes.

Figure 2 illustrates that the proposed model of Islamic corporate governance. This Islamic corporate governance is based on the Islamic worldview, whereby all elements in 
Islamic corporate governance structure shall abiding Allah SWT. The Islamic approach to corporate governance focuses on a broad spectrum of society well-being, which aims to achieve a just, participatory, and sharing socio-economic system, not only relegated to protection of stakeholders' interests. Accordingly, all economic agents in Islamic corporations shall participate in corporate decisions, to realize the objective of social wellbeing which encompassing both material and spiritual needs. Furthermore, all economic agents in Islamic corporations supposedly do not dominate each other's in achieving the objectives.

Figure 2. The Proposed Model of Islamic Corporate Governance

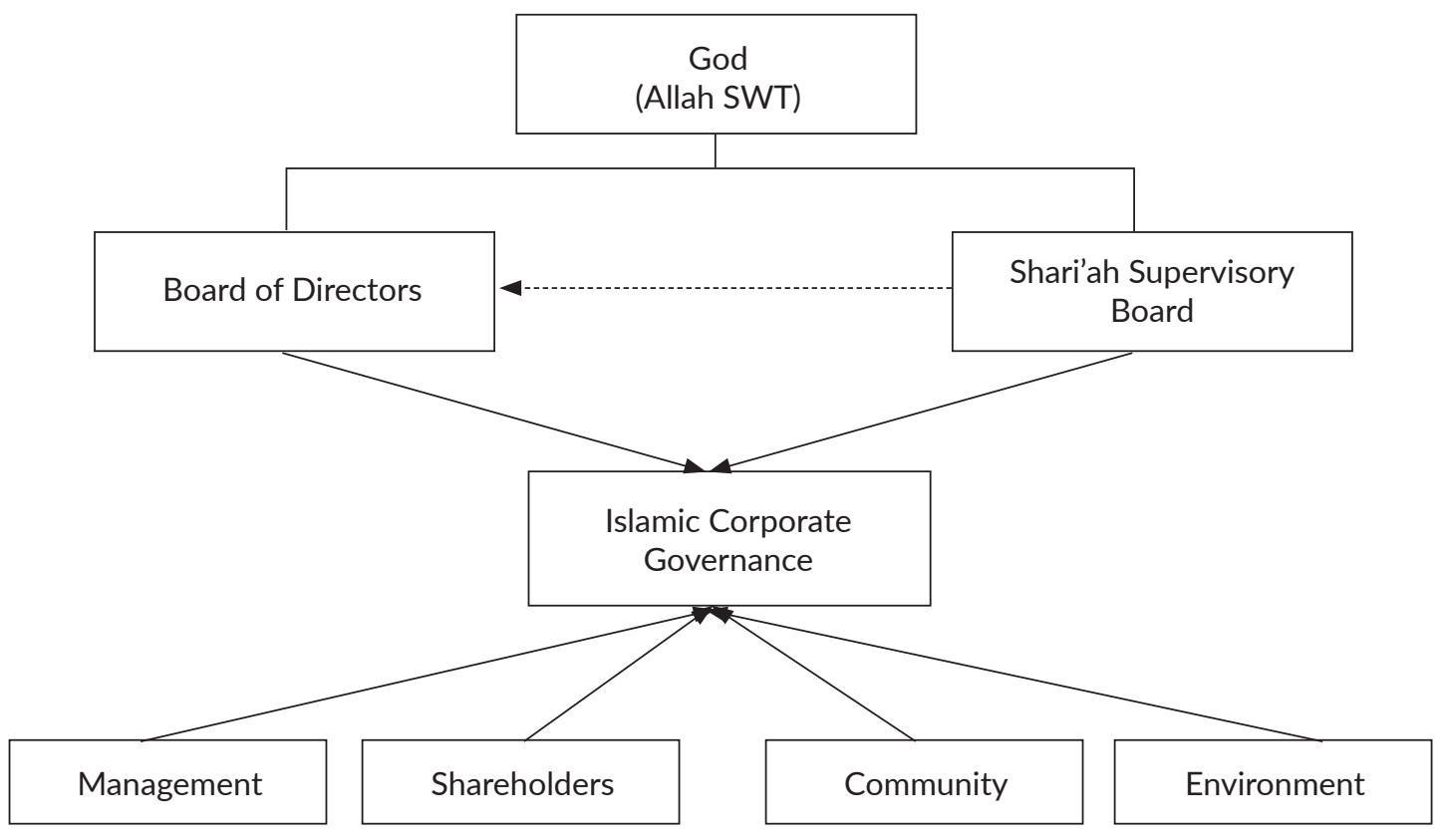

\section{Conclusion}

In conclusion, the peculiarity of Islamic corporate governance lies on specific values and Islamic norms as compared to conventional conceptions of corporate governance. Looking critically from prior literature on Islamic corporate governance, at least, three main models of Islamic corporate governance: (i) Tawhid based model, (ii) Maqasid AlShariah based model, and (iii) Stakeholder based model of corporate governance. First, Tawhid (Oneness of God) based model refers to corporate governance mechanism that derived from the principle of consultation (shura) whereby all stakeholders are driven by the same objective of Tawhid or Oneness of God. Second, the maqasid al-shariah based model concerns on the practices of corporate governance with the ultimate goal to realize maqasid al-shari'ah. Third, the stakeholder based model of corporate governance dealings with applying the stakeholders' value system with some adjustments following the Islamic norms in order to protecting the stakeholders' rights.

However, all of those Islamic corporate governance models lie beyond the aspirations of Islamic moral economy. Essentializing the aspirations of Islamic moral economy, 
Islamic corporate governance should focuses on a broad spectrum of society well-being, which aims to achieve a just, participatory, and sharing socio-economic system, not only relegated to protection of stakeholders' interests. Accordingly, all economic agents in Islamic corporations shall participate in corporate decisions, to realize the objective of social well-being which encompassing both material and spiritual needs.

Looking at the dimensions of Islamic corporate governance, we observe six critical dimensions of corporate governance from Islamic perspective, namely: (i) shari'ah scholars, (ii) stakeholders' role, (iii) responsibility, (iv) ownership, (v) transparency, and (vi) shari'ah compliance. These identified dimensions suggest an important of preserving shariah norms and values in corporate governance structure of Islamic corporations.

\section{References}

Abdallah, A. A.-N., Hassan, M. K., \& McClelland, P. L. (2015). Islamic Financial Institutions, Corporate Governance, and Corporate Risk Disclosure in Gulf Cooperation Council Countries. Journal of Multinational Financial Management, 31, 63-82. https://doi.org/10.1016/j.mulfin.2015.02.003.

Abdel-Baki, M., \& Sciabolazza, V. L. (2014). A Consensus-Based Corporate Governance Paradigm for Islamic Banks. Qualitative Research in Financial Markets, 6(1), 93-108. https://doi.org/10.1108/QRFM-01-2013-0002.

Abdul Rahman, A., \& Bukair, A. A. (2015). The Influence of the Shariah Supervision Board on Corporate Social Responsibility Disclosure by Islamic Banks of Gulf CoOperation Council Countries. Journal of Management Research, 7(2), 506.

Abdullah, W. A. W., Percy, M., \& Stewart, J. (2015). Determinants of Voluntary Corporate Governance Disclosure: Evidence from Islamic Banks in the Southeast Asian and the Gulf Cooperation Council Regions. Journal of Contemporary Accounting \& Economics, 11(3), 262-279. https://doi.org/10.1016/j.jcae.2015.10.001.

Abu-Tapanjeh, A. M. (2009). Corporate Governance from The Islamic Perspective: A Comparative Analysis with OECD Principles. Critical Perspectives on Accounting, 20(5), 556-567. https://doi.org/10.1016/j.cpa.2007.12.004.

Abu, N. Z., Jasin, D., Abdul Razak, S. H., \& Sharif, K. (2014). Corporate Governance and Maqasid Shariah: An Empirical Study on Management Practices of Takaful Operators in Malaysia. International Journal of Financial Economics, 3(1), 41-56.

Adams, R. B., Hermalin, B. E., \& Weisbach, M. S. (2010). The Role of Boards of Directors in Corporate Governance: A Conceptual Framework and Survey. Journal of Economic Literature, 48(1), 58-107.

Ahmad, S., \& Omar, R. (2016). Basic Corporate Governance Models: A Systematic Review. International Journal of Law and Management, 58(1), 73-107. https://doi. org/10.1108/ IJLMA-10-2014-0057.

Ahmed, P. (2014). Corporate Governance and Ethics of Islamic Finance Institutions. Journal of Islamic Economics, Banking and Finance, 10(1), 32-55. 
Akhtar, S. (2006). Shariah Compliant Corporate Governance. Proceeding The Annual Corporate Governance Conference (pp. 1-7). Dubai.

Al-Beshtawi, S. H., Zraqat, O. M., \& Al -Hiyasat, H. M. (2014). The Impact of Corporate Governance on Non Financial Performance in Jordanian Commercial Banks and Islamic Banks. International Journal of Financial Research, 5(3), 54-67. https://doi.org/10.5430/ijfr.v5n3p54.

Al-Malkawi, H.-A. N., Pillai, R., \& Bhatti, M. I. (2014). Corporate Governance Practices in Emerging Markets: The Case of GCC Countries. Economic Modelling, 38, 133141. https://doi.org/10.1016/j.econmod.2013.12.019.

Al-Sadah, A. K. I. (2007). Corporate Governance of Islamic Banks, Its Characteristics and Effects on Stakeholders and the Role of Islamic Banks Supervisors. (Unpublished Dissertation). University of Surrey.

Alnasser, S. A. S., \& Muhammed, J. (2012). Introduction to Corporate Governance from Islamic Perspective. Humanomics, 28(3), 220-231. https://doi.org/10.1108/ 08288661211258110 .

Archer, S., Karim, R. A. A., \& Al-Deehani, T. (1998). Financial Contracting, Governance Structures and The Accounting Regulation of Islamic Banks: An Analysis in Terms of Agency Theory and Transaction Cost Economics. Journal of Management and Governance, 2(2), 149-170.

Archer, S., \& Rifaat, A. A. K. (2013). Specific Corporate Governance Issues in Islamic Banks. In Archer, S., \& Karim, R. A. A. (Eds). Islamic Finance: The New Regulatory Challenges. Wiley Online Library. https://doi.org/10.1002/9781118390443ch17.

Asutay, M. (2013). Islamic Moral Economy as The Foundation of Islamic Finance. In Cattelan, V (Ed). Islamic Finance in Europe: Towards a Plural Financial System. Northampton: Edward Elgar.

Bakar, A. R. A. (2011). Corporate Governance: Case Study of Islamic Development Bank, Jeddah, Saudi Arabia. International Centre for Education in Islamic Finance (INCEIF).

Bektas, E., \& Kaymak, T. (2009). Governance Mechanisms and Ownership in an Emerging Market: The Case of Turkish Banks. Emerging Markets Finance and Trade, 45(6), 20-32. https://doi.org/10.2753/REE1540-496X450602.

Ben Slama Zouari, S., \& Boulila Taktak, N. (2014). Ownership Structure and Financial Performance in Islamic Banks. International Journal of Islamic and Middle Eastern Finance and Management, Emerald, 7(2), 146-160. https://doi.org/10.1108/ IMEFM-01-2013-0002.

Bhatti, M., \& Bhatti, I. (2009). Development in legal Issues of Corporate Governance in Islamic Finance. Journal of Economic and Administrative Sciences, 25(1), 67-91. https://doi.org/10.1108/10264116200900004.

Bouzenita, A. I. (2012). Early Contributions to The Theory of Islamic Governance: Abd Al-Rahman Al-Awza'i. Journal of Islamic Studies, 23(2), 137-164.

Brown, P., Beekes, W., \& Verhoeven, P. (2011). Corporate Governance, Accounting and 
Finance: A Review. Accounting and Finance, 51(1), 96-172. https://doi.org/10.1111/ j.1467-629X.2010.00385.x.

Bukair, A. A., \& Rahman, A. A. (2015). Bank Performance and Board of Directors Attributes by Islamic Banks. International Journal of Islamic and Middle Eastern Finance and Management, 8(3), 291-309. https://doi.org/10.1108/IMEFM-10-2013-0111.

Bukhari, K. S., Awan, H. M., \& Ahmed, F. (2013). An Evaluation of Corporate Governance Practices of Islamic Banks versus Islamic Bank Windows of Conventional Banks: A Case of Pakistan. Management Research Review, 36(4), 400-416. https:// doi.org/10.1108/01409171311315003.

Casciaro, T., \& Piskorski, M. J. (2005). Power Imbalance, Mutual Dependence, and Constraint Absorption: A Closer Look at Resource Dependence Theory. Administrative Science Quarterly, 50(2), 167-199. https://doi.org/10.2189/ asqu.2005.50.2.167.

Chang, K., Kang, E., \& Li, Y. (2016). Effect of Institutional Ownership on Dividends: An Agency-Theory-Based Analysis. Journal of Business Research, 69(7), 2551-2559. https://doi.org/10.1016/j.jbusres.2015.10.088.

Chapra, M. U. (2004). Stakeholders Model of Governance in Islamic Economic System. Comments: Muhammad Umer Chapra. Islamic Economic Studies, 11(2), 43-63.

Chapra, M. U., \& Ahmed, H. (2002). Corporate Governance in Islamic Financial Institutions. Occasional Paper No. 6, Jeddah, IRTI/IDB, (6), 1-170.

Chen, H.-L., Hsu, W.-T., \& Chang, C.-Y. (2016). Independent Directors' Human and Social Capital, Firm Internationalization and Performance Implications: An Integrated Agency-Resource Dependence View. International Business Review, 25(4), 859-871. https://doi.org/10.1016/j.ibusrev.2015.10.010.

Choudhury, M. A., \& Hoque, M. Z. (2006). Corporate Governance in Islamic Perspective. Corporate Governance, 6(2), 116-128. https://doi.org/10.1108/14720700610655132.

Claessens, S., \& Fan, J. P. H. (2002). Corporate Governance in Asia: A Survey. International Review of Finance, 3(2), 71-103. https://doi.org/10.1111/1468-2443.00034.

Claessens, S., \& Yurtoglu, B. B. (2013). Corporate Governance in Emerging Markets: A Survey. Emerging Markets Review, 15, 1-33. https://doi.org/10.1016/j.ememar.2012.03. 002.

Crutchley, C. E., \& Hansen, R. S. (1989). A Test of the Agency Theory of Managerial Ownership, Corporate Leverage, and Corporate Dividends. Financial Management, 18(4), 36-46.

Daily, C. M., Dalton, D. R., \& Cannella, A. A. (2003). Corporate Governance: Decades of Dialogue and Data. Academy of Management Review, 28(3), 371-382.

Dalwai, T. A. R., Basiruddin, R., \& Abdul Rasid, S. Z. (2015). A Critical Review of Relationship Between Corporate Governance and Firm Performance: GCC Banking Sector Perspective. Corporate Governance, 15(1), 18-30. https://doi.org/10.1108/ CG-04-2013-0048.

Darmadi, S. (2013). Corporate Governance Disclosure in The Annual Report: An Exploratory Study on Indonesian Islamic Banks. Humanomics, 29(1), 4-23. https:// doi.org/10.1108/08288661311299295. 
Dusuki, A. W. (2012). Corporate Governance and Stakeholder Management: An Islamic Perspective. ISRA International Journal of Islamic Finance, 4664(August), 1-22.

Elias, J. J. (2015). Aisha's Cushion: Religious Art, Perception, and Practice in Islam. Harvard University Press.

Eisenhardt, K. M. (1989). Agency Theory: An Assessment and Review. Academy of Management Review, 14(1), 57-74.

Ghayad, R. (2008). Corporate Governance and The Global Performance of Islamic Banks. Humanomics, 24(3), 207-216. https://doi.org/10.1108/08288660810899368.

Ginena, K. (2014). Sharī'ah Risk and Corporate Governance of Islamic Banks. Corporate Governance, 14(1), 86-103. https://doi.org/10.1108/CG-03-2013-0038.

Grassa, R. (2013). Shariah Supervisory System in Islamic Financial Institutions. Humanomics, 29(4), 333-348. https://doi.org/10.1108/H-01-2013-0001.

Grassa, R. (2016). Ownership Structure, Deposits Structure, Income Structure and Insolvency Risk in GCC Islamic Banks. Journal of Islamic Accounting and Business Research, 7(2), 93-111. https://doi.org/10.1108/JIABR-11-2013-0041.

Grassa, R., \& Matoussi, H. (2014). Corporate Governance of Islamic Banks: A Comparative Study Between GCC. International Journal of Islamic and Middle Eastern Finance and Management, 7(3), 346-362. https://doi.org/10.1108/IMEFM-01-2013-0001.

Hamza, H. (2013). Sharia Governance in Islamic Banks: Effectiveness and Supervision Model. International Journal of Islamic and Middle Eastern Finance and Management, 6(3), 226-237. https://doi.org/10.1108/IMEFM-02-2013-0021.

Haniffa, R., \& Hudaib, M. (2007). Exploring the Ethical Identity of Islamic Banks via Communication in Annual Reports. Journal of Business Ethics, 76(1), 97-116.

Hasan, Z. (2009). Corporate Governance: Western and Islamic Perspectives. International Review of Business Research Papers, 5(1), 277-293.

Hasan, Z. (2012). Corporate Governance in Islamic Financial Institutions: An Ethical Perspective. Prime Journal of Business Administration and Management, 2(1), 1-8.

Hashim, F., Mahadi, N. D., \& Amran, A. (2015). Corporate Governance and Sustainability Practices in Islamic Financial Institutions: The Role of Country of Origin. Procedia Economics and Finance, 31, 36-43. https://doi.org/10.1016/S2212-5671(15)01129-6.

Hillman, A. J., \& Dalziel, T. (2003). Boards of Directors and Firm Performance: Integrating Agency and Resource Dependence Perspectives. Academy of Management Review, 28(3), 383-396.

Hillman, A. J. W. (2009). Resource Dependence Theory: A Review. Journal of Management, 35(6), 1404-1427. https://doi.org/10.1177/0149206309343469.

Hoong, P. Y., \& Sin, L. K. (2006). Recent Developments in Corporate Governance in Singapore. Journal of Corporate Finance, 12(3), 381-402.

Iqbal, Z., \& Mirakhor, A. (2004). Stakeholders Model of Governance in Islamic Economic System. Islamic Economic Studies, 11(2), 43-63. 
Ismail, N. A., \& Razak, S. H. A. (2014). Shariah Governance Framework Gaps and Issues. International Journals of Financial Economics, 3(1), 1-10.

ISRA \& Thomson Reuters. (2016). Islamic Commercial Law Report 2016. Malaysia: ISRA. Jackling, B., \& Johl, S. (2009). Board Structure and Firm Performance: Evidence from India's Top Companies. Corporate Governance: An International Review, 17(4), 492509. https://doi.org/10.1111/j.1467-8683.2009.00760.x.

Jensen, M. C. (1986). Agency Costs of Free Cash Flow, Corporate Finance, and Takeovers. American Economic Review, 76(2), 323-329.

John, K., De Masi, S., \& Paci, A. (2016). Corporate Governance in Banks. Corporate Governance: An International Review, 24(3), 303-321.

Kasim, N., Ibrahim, S. H. M., \& Sulaiman, M. (2009). Shariah Auditing in Islamic financial Institutions: Exploring the Gap Between The "Desired" and the "Actual." Global Economy and Finance Journal, 2(2), 127-137.

Kiel, G. C., \& Nicholson, G. J. (2003). Board Composition and Corporate Performance: How The Australian Experience Informs Contrasting Theories of Corporate Governance. Corporate Governance: An International Review, 11(3), 189-205. https:// doi.org/10.1111/1467-8683.00318.

Krafft, J., \& Ravix, J.-L. (2008). Corporate Governance and The Governance of Knowledge: Rethinking the Relationship in Terms of Corporate Coherence. Economics of Innovation and New Technology, 17(1), 79-95. https://doi.org/10.1080/ 10438590701279359.

Kumar, R. (2011). Research Methodology: A Step by Step Guide fro Begineers. Sage: New Delhi. Lahsasna, A. (2014). Shariah Governance in The Islamic Financial Institutions: Issues and Challenges. Proceeding at the $5^{\text {th }}$ Internatinal Conference on Business and Economic Research.

Levine, R. (2004). The Corporate Governance of Banks: A Concise Discussion of Concepts and Evidence. World Bank Publications.

Lewis, M. K. (2005). Islamic Corporate Governance. Review of Islamic Economics, 9(1), 5-29.

Maurovic, L., \& Hasic, T. (2015). Revision of Shareholder Rights Directive a Critical Review. Proceeding Conference Proceedings of the International Scientific Conference (p. 253).

Mizushima, T. (2013). Corporate Governance and Shariah Governance at Islamic Financial Institutions: Assessing from Current Practice in Malaysia. Reitaku Journal of Interdisciplinary Studies, 22(1), 59-84.

Mohammed, S. A. S. A. N., \& Muhammed, J. (2017). The Relationship Between Agency Theory, Stakeholder Theory, and Shariah Supervisory Board in Islamic Banking: An Attempt Towards Discussion. Humanomics, 331), 75-83. https://doi. org/10.1108/H-08-2016-0062.

Mollah, S., \& Zaman, M. (2015). Shari'ah Supervision, Corporate Governance and Performance: Conventional vs. Islamic Banks. Journal of Banking \& Finance, 58, 418-435. https://doi.org/10.1016/j.jbankfin.2015.04.030. 
Muneeza, A. (2014). Shari'ah Governance Applicable to Islamic Banks in Malaysia: Effect of Islamic Financial Services Act 2013. Contemporary Studies in Economic and Financial Analysis, 95, 31-44. https://doi.org/10.1108/S1569-3759(2014)0000095010.

Nathan, S., \& Ribière, V. (2007). From Knowledge to Wisdom: The Case of Corporate Governance in Islamic Banking. Vine, 37(4), 471-483. https://doi.org/10.1108/ 03055720710838533.

OECD. (2015). OECD Principles of Corporate Governance. OECD. https://doi.org/http:// dx.doi.org/10.1787/9789264236882-

Pfeffer, J. (1972). Size and Composition of Corporate Boards of Directors: The Organization and Its Environment. Administrative Science Quarterly, 218-228. https://doi.org/10.2307/2393956.

Pfeffer, J., \& Salancik, G. (1978). The External Control of Organizations: A Resource Dependence Perspective. New York: Harper and Row.

Rosly, S. A. (2010). Shariah Parameters Reconsidered. International Journal of Islamic and Middle Eastern Finance and Management, 3(2), 132-146. https://doi.org/10.1108/ 17538391011054372.

Safieddine, A. (2009). Islamic Financial Institutions and Corporate Governance: New Insights for Agency Theory. Corporate Governance: An International Review, 17(2), 142-158. https://doi.org/10.1111/j.1467-8683.2009.00729.x.

Sam, C. Y. (2007). Corporate Governance Reforms in The Post-1997 Asian Crisis: Is There Really a Convergence to The Anglo-American Model? Global Economic Review, 36(3), 267-286.

Shafii, Z., Ali, N. A. M., \& Kasim, N. (2014). Shariah Audit in Islamic Banks: An Insight to the Future Shariah Auditor Labour Market in Malaysia. Procedia - Social and Behavioral Sciences, 145, 158-172. https://doi.org/10.1016/j.sbspro.2014.06.023.

Sharma, P. K. (2014). Corporate Governance and Firm Performance in Indian Listed Companies. International Journal of Governance, 4(1), 1-18.

Shibani, O., \& Fuentas, C. D. (2017). Differences and Similarities Between Corporate Governance Principles in Islamic Banks and Conventional Banks. Research in International Business and Finance, 42(C), 1005-1010. https://doi.org/10.1016/j.ribaf.2017.07.036.

Škare, M., \& Hasić, T. (2016). Corporate Governance, Firm Performance, and Economic Growth - Theoretical Analysis. Journal of Business Economics and Management, 17(1), 35-51. https://doi.org/10.3846/16111699.2015.1071278.

Srairi, S. (2015). Corporate Governance Disclosure Practices and Performance of Islamic Banks in GCC Countries. Journal of Islamic Finance, 4(2), 1-17.

Ullah, H. (2014). Shari'ah Compliance in Islamic Banking. International Journal of Islamic and Middle Eastern Finance and Management, 7(2), 182-199. https://doi. org/10.1108/ IMEFM-06-2012-0051.

Van Essen, M., Engelen, P. J., \& Carney, M. (2013). Does “Good” Corporate Governance Help in a Crisis? The Impact of Country- and Firm-Level Governance Mechanisms in The European Financial Crisis. Corporate Governance, 21(3), 201-224. 
Wijethunga, I. I., \& Ekanayake, E. M. N. N. (2015). Element of Corporate Governance in Islamic Banks vs Conventional Banks: A Case Study. Journal of Islamic Banking and Finance, 3(1), 44-49.

Wilson, R. (2009). Shari'ah Governance for Islamic Financial Institutions. ISRA International Journal of Islamic Finance, 1(1), 59-75.

Zain, N. R. B. M., Zulkarnain, I. F. B., \& Hassan, P. D. R. (2015). Shari'ah Corporate Governance Structure of Malaysian Islamic Banking and Finance: The Traces of Shura. Journal of Islamic Banking and Finance, 3(1), 26-34. 